\title{
Development of Methods Ensuring Balanced Budgets in the Medium Term
}

\begin{abstract}
Submitted 21/01/19, $1^{\text {st }}$ revision 24/02/19, $2^{\text {nd }}$ revision 04/04/19, accepted 25/05/19
L.V. Bogoslavtseva ${ }^{1}$, O.Y. Bogdanova ${ }^{2}$, O.I. Karepina ${ }^{3}$, O.S. Dzhu ${ }^{4}$

Abstract:

Purpose: The study aims to identify the prospects for the application of modern methods of balancing the budgets of the constituent entities of the Russian Federation.

Design/Methodology/Approach: The formation of balanced budgets of the constituent entities of the Russian Federation is intended to provide funding for priority expenditures of the regions effectively, predetermining the need to identify the features of the implementation of scientific theories about the balance of budgets, to highlight the problems of the budget legislation of the Russian Federation and to determine the prospects for the use of traditional and new market methods of regulating the basic parameters of budgets.

Findings: Authors grounded the need for complex application of methods of balancing budgets for the main parameters to increase tax and non-tax revenues, the formation of expenses regarding their optimization and efficiency, weighted debt policy, improving intergovernmental relations. The authors recommended the development of standards for applying methods of balancing budgets.

Practical implications: The results of the study can be considered in the practice of forming the basic parameters of the budgets of the constituent entities of the Russian Federation in the context of limited budget funds to strengthen budget revenues.

Originality/Value: The main contribution of this study is to justify the complexity of the application of methods of balancing budgets, as well as to shift the emphasis on the regulation of domestic debt relations in the context of economic uncertainty.
\end{abstract}

Keywords: Balanced budget, budget indicators, balancing methods.

JEL Codes: H61, H69.

Paper Type: Research article in a Special Issue dedicated to Russian economy.

Section 8: Business and Economic Issues.

\footnotetext{
${ }^{l}$ PhD, Associate Professor, Department of Finance, Rostov State University of Economics, Rostov-on-Don, Russian Federation, b_ludmila@bk.ru

${ }^{2}$ Associate Professor, Department of Finance, Rostov State University of Economics, Rostovon-Don, Russian Federation.

${ }^{3}$ PhD, Associate Professor, Department of finance, Rostov State University of Economics, Rostov-on-Don, Russian Federation.

${ }^{4}$ Postgraduate student, Rostov State University of Economics, Rostov-on-Don.
} 


\section{Introduction}

Ensuring the formation and execution of balanced budgets of the budget system under risk-oriented factors influencing the financial state of legal entities territories (the RF, constituent entities of the RF, municipalities) is a necessary condition of effective management of budgetary flows and the implementation of the developed budget policy. A balanced state of the budget in a formalized way does not raise discussions and presupposes equality of revenues and expenditures of budgets. But a mechanism for balanced budgets is of theoretical and practical interest in terms of making timely decisions on preserving proportions of major budget indicators by public authorities considering changing internal and external conditions.

\section{Materials and Methods}

Against the background of constantly changing economic and political conditions, the gap between theory and practice in the field of balanced budgets increased, which led to decision-making by the authorities in accordance with the current economic situation. Based on the peculiarities of economic relations in the Russian financial science, two economic schools are clearly defined: reproduction and distribution (Rodionova, 2009). In the practical aspect of forming and executing of a balanced budget, in our opinion, it is necessary to consider the provisions and the arguments of two theoretical concepts. The issues of budget legal relations and the balance in budgets investigated at the regional level (Kuznetsov et al., 2013). In addition, we consider it necessary to take into account the results of the evolution of a theoretical economic thought about the role of the state in making decisions on regulating state financial flows when choosing methods of balancing budgets (Bogoslavtseva, 2012).

In our opinion, despite debates about the role of the state, the functions of finance and budget in the regulation of budgetary issues in domestic and foreign economic and financial science at the present stage is in the process of convergence. However, the main problem lies behind the external simplicity of solving the problem. It is choosing the optimal set of methods for balancing budgets for each country. The development of standards for the application of methods of balancing budgets in various economic situations seems to be able to strengthen the basic indicators of budgets, but this is a task for the future. Consequently, the reality of the current complex geopolitical situation is that it is necessary to use the best global practices of balanced budgets, considering peculiarities and a risk-oriented approach to generate budget indicators for each country.

\section{Results}

The recommendations of scientists, which are of practical importance for balancing budgets, become the general socio-economic strategy of the state and are used in the development of a budget policy. Theoretical provisions are reflected in the budget 
legislation regulating practical issues of budget legal relations. Thus, in the Budget Code of the Russian Federation, various states of the budget implying the use of certain methods to ensure its balance and finance expenditure commitments in full are defined. Table 1 reflects it.

Table 1. The ratio between budget revenues and expenditures in accordance with the provisions of the Budget Code of the Russian Federation

\begin{tabular}{|l|l|}
\hline $\begin{array}{l}\text { Ratio of budget revenues } \\
\text { to budget expenditures }\end{array}$ & \multicolumn{1}{c|}{ Articles of the Russian Budget Code } \\
\hline $\begin{array}{l}\text { Deficit = Expenditures - } \\
\text { revenues }\end{array}$ & $\begin{array}{l}\text { Art. 6: "Budget deficit: excess of budget expenditures over its } \\
\text { revenues" }\end{array}$ \\
\hline $\begin{array}{l}\text { Surplus = Revenues - } \\
\text { expenditures }\end{array}$ & $\begin{array}{l}\text { Art. 6: "Budget surplus: excess of budget revenues over its } \\
\text { expenditures" }\end{array}$ \\
\hline $\begin{array}{l}\text { Balance: } \\
\text { Revenues = Expenditures }\end{array}$ & $\begin{array}{l}\text { Art.33: "The principle of a balanced budget means that the } \\
\text { amount of envisaged budget expenditures must correspond to } \\
\text { the total amount of budget revenues and the sources of } \\
\text { financing for its deficit reduced by the amount of payments } \\
\text { from the budget related to the sources of financing the budget } \\
\text { deficit and changes in account balances on accounting for } \\
\text { buget funds". }\end{array}$ \\
\hline
\end{tabular}

It is the principle of a balanced budget that involves the search for and use of various methods for generating budget revenues and expenditures, as well as attracting sources of financing the budget deficit to achieve a balance between budget revenues and their use.

Revenues and expenditures are important indicators of the budget, on which the level of balance depends. Both indicators are important for the implementation of the country's budgetary policy. It is interesting to note that at the stage of drawing up a draft budget, the amounts of income and expenditures are determined simultaneously, considering the current regulatory documents. At the stage of budget execution, expenditure commitments change depending on revenues received.

\section{Discussion}

The tax and budget legislation of the Russian Federation establishes the revenues assigned to corresponding budgets on an ongoing basis, which can be called the first indicator of the budget. This predetermines the sustainability of revenues to the budgets of the country's budget system and creates opportunities for their stable growth. The main instrument in terms of strengthening budget revenues is the standards of deductions from taxes of the tax system of the country to budgets of different levels. Types of taxes and fees as well as special tax regimes are defined in the Tax Code of the Russian Federation at the federal, regional and municipal levels. The standards for tax deductions are approved in the Budget Code of the Russian Federation. In addition, regional regulatory documents are developed and approved on the calculation and levying revenue sources of budgets, but only within the 
framework of the powers transferred to the regions by federal legislation.

It should be noted that in 2019, federal budget revenues are expected to increase relative to GDP, which is associated with the proposed changes in tax legislation (primarily, an increase in the VAT rate from 18 to 20\%) and changes in macroeconomic indicators. It will compensate for the decline in oil and gas revenues compared to the current year due to the anticipated decline in the price of oil (BTC Directions, 2019). However, in practice, the tax base is distributed extremely unevenly by individual territories, which predetermines the main tasks in the search for reserves for the growth of the budget revenue base.

In the light of the current tax and budget legislation, it seems necessary to monitor the objects of taxation or the collection of income from the use of property; check the correctness of the application of the investment tax deduction and tax breaks on the property tax of organizations with respect to movable property, etc.

In the medium term, support from the federal budget in strengthening regional revenues will be continued by providing non-repayable receivables in the form of inter-budgetary transfers, including subsidies to equalize the fiscal capacity of the constituent entities of the Russian Federation, which will retain the leading role in the system of inter-budget regulation. The Government of the Russian Federation plans to reduce the provision of subsidies and other intergovernmental transfers, including through consolidation based on the need to unite various types of transfers provided for the same purposes. It is reflected in the main directions of the fiscal, tax and customs tariff policy for 2019 and the planning period of 2020 and 2021. Besides, problems and prospects for balancing the Pension Fund of the Russian Federation in the part that is not related to the formation of funds for financing accumulative pensions will also be provided from the federal budget in the form of an interbudgetary transfer to compulsory pension insurance (Ekimova et al., 2018).

The limited reserves of growth in budget revenues underscore the importance of the theoretical concept of the distributional nature of finance and budget and the importance of creating conditions for real GDP growth.

The second indicator, which determines the balance of the budget, includes budget expenditures. Regarding the regulation of expenditures of the budgets of the budget system of the country, the following methods are used to ensure balance:

- limitation and optimization of budget expenditures, that is, the establishment of their limiting values for each state and municipal institution for each type of expenditure; - result-oriented budgeting and improving the efficiency of budget expenditures;

- program-targeted funding with the establishment of criteria for achieving the objectives of the program. For example, "25 out of 34 member countries of the Organization for Economic Cooperation and Development (OECD) have switched or 
are planning to make a transition to a program budget, its main goal being increasing the socio-economic efficiency of public spending " (Miroshnikov and Charkina, 2019).

At the present stage, one of the most important tasks of the executive authorities, primarily financial bodies, in the domestic practice is the continuation of work to bring the expenditure obligations of the Russian Federation, constituent entities of the Russian Federation and municipalities in line with the separation of powers. Another task is "ensuring the effective and responsible management of the management of state programs in Russia” (Romanova et al., 2018).

According to the main directions of budget, tax and customs tariff policy for 20192021, as one of new measures to improve the efficiency of the budget funds use, a system of managing tax expenditures (lost budget revenues due to tax concessions, tax and fee preferences envisages as measures of state support in accordance with the objectives of state programs and (or) goals of socio-economic policy not related to state programs) will be implemented. Its integration into the budget process will be also ensured.

The dynamics of the main parameters of the budget system of the Russian Federation in 2019-2021 is characterized by a decrease in income and expenditure relative to GDP while the deficit is reduced from $1.6 \%$ of GDP in 2019 to $0.7 \%$ of GDP by 2021 , which is reflected in Table 2.

Table 2. Changes in the share of budget revenues and expenditures of the budget system in GDP in 2019-2021 (Compiled by the authors on the basis of BTC Directions, 2019)

\begin{tabular}{|l|l|}
\hline \multicolumn{1}{|c|}{$\begin{array}{c}\text { Share of budget revenues and } \\
\text { expenditures of the budget system in } \\
\text { GDP }\end{array}$} & \multicolumn{1}{|c|}{$\begin{array}{c}\text { Share of budget expenditures of the } \\
\text { budget system in GDP }\end{array}$} \\
\hline $\begin{array}{l}\text { - increases by } 0.3 \text { percentage point in } 2019 \\
\text { compared to 2018, }\end{array}$ & $\begin{array}{l}\text { - decreases by } 0.4 \text { percentage point in } 2019 \\
\text { compared to } 2018,\end{array}$ \\
\hline $\begin{array}{l}\text { - decreases by } 0.5 \text { percentage point in } 2020 \\
\text { compared to 2019, }\end{array}$ & $\begin{array}{l}\text { - increases by } 0.1 \text { percentage point in } 2020 \\
\text { compared to } 2019,\end{array}$ \\
\hline $\begin{array}{l}\text { - decreases by } 0.5 \text { percentage point in } 2021 \\
\text { compared to 2020. }\end{array}$ & $\begin{array}{l}\text { - decreases by } 0.3 \text { percentage point in } 2021 \\
\text { compared to } 2020 .\end{array}$ \\
\hline
\end{tabular}

To fulfill the planned budget indicators of the budget system of the country, a transition to the formation of budgets on the basis of new "fiscal rules" was made. These rules set the maximum amount of federal budget expenditures as the sum of the base oil and gas revenues calculated with the base oil price of $\$ 40$ per barrel of "Urals" oil (with the annual indexation by $2 \%$ since 2018), the volume of non-oil revenues and expenses for servicing the public debt (BTC Directions, 2019). In turn, additional oil and gas revenues will be used to form the National Wealth Fund, its funds being available for co-financing voluntary pension savings of citizens of the 
Russian Federation. The use of the NWF funds to finance the federal budget deficit or the budget of the Pension Fund of the Russian Federation is not expected in the medium term.

The third indicator of a balanced budget in domestic practice at the present stage is the sources of financing the budget deficit, which, on the one hand, reduce the budget deficit, and, on the other hand, lead to an increase in the state (municipal) debt. Articles 94-96 of the Budget Code of the Russian Federation identify possible sources of financing budget deficits. However, their use leads to the emergence of debt relations. Debt management in the regions and municipalities depends on the difference in the socio-economic development of individual territories and on the factors affecting the assessment of the creditworthiness of the subjects of the Russian Federation, which is reflected in Table 3.

Table 3. Factors influencing creditworthiness assessment (debt policy) of the constituent entities of the Russian Federation (Compiled by the authors on the basis of Strelnikova, 2018)

\begin{tabular}{|c|c|}
\hline $\begin{array}{l}\text { Factors negatively influencing } \\
\text { creditworthiness }\end{array}$ & Factors supporting creditworthiness \\
\hline \multicolumn{2}{|c|}{ Factors influencing the rankings in the medium term } \\
\hline $\begin{array}{l}\text { - maintaining pressure on the budget } \\
\text { system of the country as a whole; } \\
\text { - stagnant tax revenues due to slow } \\
\text { economic recovery; } \\
\text { - uncertainty of political decisions in the } \\
\text { post-election period and, as a result, the risk } \\
\text { of growth of current expenditures; } \\
\text { - rejection of the practice of granting new } \\
\text { budget loans, which leads to an increase in } \\
\text { the cost of borrowing; } \\
\text { - reduced budget flexibility as a result of } \\
\text { ongoing cost optimization practices. }\end{array}$ & $\begin{array}{l}\text { - restructuring of budget loans with an } \\
\text { increase in their maturity; } \\
\text { - increased control by the federal } \\
\text { government over the level of debt and } \\
\text { deficit; } \\
\text { - the positive effect of changes in the } \\
\text { calculation of subsidies for most regions; } \\
\text { - recovery of economic growth in most } \\
\text { regions; } \\
\text { - optimization of budget expenditures and } \\
\text { control over them; } \\
\text { - moderate lengthening of the debt profile } \\
\text { due to new bond issues against the } \\
\text { background of reducing the cost of market } \\
\text { borrowings. }\end{array}$ \\
\hline \multicolumn{2}{|c|}{ Factors influencing the rankings in the long term } \\
\hline $\begin{array}{l}\text { - low budget flexibility as a result of high } \\
\text { centralization of decision-making at the } \\
\text { federal level and low capital expenditures; } \\
\text { - frequent changes in fiscal legislation; } \\
\text { problems of long-term financing, weak } \\
\text { linkage of debt and investment policies, lack } \\
\text { of long-term budget planning. }\end{array}$ & $\begin{array}{l}\text { - maintaining a managed debt load in } \\
\text { combination with lengthening of the debt } \\
\text { profile and smoothing the peak payments on } \\
\text { the debt; } \\
\text { - strong operational performance } \\
\text { indicators of the budget as a result of a } \\
\text { balanced fiscal policy; } \\
- \text { transition to a balanced (vertical and } \\
\text { horizontal) and sustainable system of } \\
\text { intergovernmental relations. }\end{array}$ \\
\hline
\end{tabular}


It should be noted that modern methods of managing the sub-federal debt include: provision of state guarantees, development of the infrastructure of the domestic subfederal debt market; attraction of new borrowings; implementation of state financial control over the efficiency of management of the sub-federal debt, which is actually aimed at identifying reserves for reducing the debt burden of the budgets of the constituent entities of the Russian Federation.

The use of borrowings to attract additional investments by the authorities is a positive international experience. However, in our opinion, this experience is such only if the budget is balanced, when borrowing, in fact, plays the role of attracting targeted investments aimed at the socio-economic development of the subjects of the Russian Federation.

The second important difference of sub-federal borrowings in Russia from the best global practices of territorial borrowings lies in their structure. In world practice, government securities and loans of credit organizations are effective instruments of debt relations. However, the Russian market of sub-federal securities did not receive corresponding development due to the problem of their placement and mistrust to them on the part of investors. It is also quite difficult for regional authorities to get a credit from a credit institution in the context of a budget deficit, and therefore, there is no real amount for loans repayments and interest payments on them.

In the current conditions of economic uncertainty, the implementation of the budget policy of the subjects of the Russian Federation is aimed at ensuring the balance of regional budgets primarily by strengthening their own revenue base and improving the efficiency of regional budget expenditures. Bank loans, involving the use of higher interest rates, can provide investment income at a time of receiving a loan, but at the same time dramatically increase the cost of servicing and repaying bank borrowings.

Strengthening the budgets of the territories seems to expand the use of methods and forms of borrowing, including government sub-federal securities. At the present stage, the process of attracting sub-federal loans cannot be recognized as effective for the following reasons:

- in accordance with Article 111 of the Budget Code, budget expenditures for servicing the state debt of a constituent entity of the Russian Federation under section 14 "Intergovernmental transfers of a general nature" should not exceed 15 percent of the corresponding budget expenditures. However, this is a fairly high percentage, which leads to an increase in the debt of the constituent entities of the Russian Federation. Such a high percentage does not reflect the solvency risks of the region; - indicators of debt sustainability are insufficient.

A complex of indicators of real debt dependence or sustainability of regional budgets has not been developed. The budget legislation defines only two indicators characterizing the debt relations of a constituent entity of the Russian Federation: the 
first indicator is the ratio of the public debt of a constituent entity of the Russian Federation to the total amount of revenues of the regional budget, excluding gratuitous receipts from the federal budget; the second indicator is the share of expenses for servicing and repaying the state debt of a constituent entity of the Russian Federation in the total amount of expenditures of the regional budget.

However, the economic literature devoted to debt relations in the constituent entities of the Russian Federation contain the following point of view. It entails that using only these indicators does not allow giving a real and reliable characteristics of debt sustainability of the corresponding subject of the Russian Federation. The study identified the main risks of implementing the debt policy of Rostov region, which include:

- the risk of interest rates rising and changes in the cost of borrowing depending on the time and volume of demand for borrowed resources;

- the risk of insufficient revenue receipts in the regional budget.

In general, to achieve sustainability of the budgets of the constituent entities of the Russian Federation and reduce the need for credit resources, it is necessary to ensure:

$\checkmark$ the direction of additional revenues received during the execution of the budgets of the constituent entities of the Russian Federation for early repayment of the region's debt obligations or replacement of borrowed funds;

$\checkmark$ preventing new spending commitments that are not secured by stable sources of income;

$\checkmark$ constant monitoring of the compliance of parameters of the deficit and the public debt of a constituent entity of the Russian Federation with the restrictions established by the Budget Code of the Russian Federation and agreements concluded with the Ministry of Finance of Russia.

In 2019, it is planned to use such a supplementary tool as the Development Fund in terms of the domestic practice, which is being formed in the structure of the federal budget. Sources of financing for the fund should be domestic borrowing, and the fund should be used for the creation of new assets, for capital investments, for the creation and stimulation of the economy, and not for current consumption.

\section{Conclusion}

Thus, according to the Ministry of Finance of the Russian Federation, the planned policy of balancing the budget due to the growth of the real sector of the economy, the policy of implementing the new "budget rules" and applying a new instrument the Development Fund - are designed to gradually reduce the non-oil deficit to $6.0 \%$ of GDP. 
The development and application of methods of balancing budgets in the medium term, in our opinion, require:

- ensuring real GDP growth due to an active state policy in the field of innovation and investment development;

- further development of incentives to increase budget revenues, not only by increasing tax rates, but by strengthening the tax potential of the territory;

- adjustments to the mechanisms for providing financial assistance to lower budgets, considering their resolution of ambitious priorities;

- improvement of the system of delimitation of expenditure obligations between state and local authorities;

- real formation and performance of the Development Fund;

- consider the risks of implementing the basic parameters of budgets;

- increase the openness of budgets, monitor and exercise the state financial control over budget flows at all stages of the budget process.

In conclusion, it is of note that the provisions of the Decree of the President of the Russian Federation No. 204 of May 7, 2018 "On the national goals and strategic objectives of the development of the Russian Federation for the period up to 2024", the messages of the President of the Russian Federation to the Federal Assembly of the Russian Federation, as well as the main directions of the fiscal, tax and customs tariff policy of the country for 2019-2021 developed and approved by the Ministry of Finance of Russia are focused on the main financial goal. The goal is to ensure the sustainable economic growth rate and expand country's potential for balanced development. Thus, realizing the principle of balanced budgets, financiers manage the movement of all financial flows, applying methods of regulating revenues, budget expenditures, the state (municipal) debt, mediating basic budget indicators, which is intended to ensure the highest possible balance of budgets of all levels.

\section{References:}

Bogoslavtseva, L.V. 2012. The genesis of the definition of "financial flows" in terms of the evolution of theoretical economic thought. Financial research, 4, 13-21.

BTC Directions. 2019. The Main directions of the budget, tax and customs tariff policy for 2019 and the planned period of 2020 and 2021 . Available at: http://www.consultant.ru.

Ekimova, K.V., Bogdanova, O.Y., Karepina, O.I., Kravchenco, E.V. 2018. Pension Fund of The Russian Federation: challenges and prospects of the development under modern conditions. European Research Studies Journal, 21(S3).

Ivanova, O.B., Bogoslavtseva, L.V., Karepina, O.I., Kostoglodova, E.D. 2017. Providing the budget transparency and state projects efficiency monitoring in RUSSIA. European Research Studies Journal, 20(1), 97-104.

Ivanova, O.B., Vovchenko, N.G., Kostoglodova, E.D., Bogoslavtseva, L.V., Rukina, S.N., Karepina, O.I. 2017. Financial transparency in budget sector of economy as a necessary condition of clustering. International Journal of Trade and Global Markets, 2-3(10), 207-216. 
Kuznetsov, N.G., Kochmola, K.V., Alifanova, E.N. 2013. Finance and credit. Moscow, KnoRus, 346.

Miroshnikov, S.N., Charkina, E.S. 2017. Reforming state finances: foreign experience and Russian problems. Russian Entrepreneurship, 4(18).

Rodionova, V.M. 2009. Formation and development of a research school in finance. Vestnik of the Finance Academy, 1, 11.

Romanova, T.F., Bogoslavtseva, L.V., Karepina, O.I., Bogdanova, O.Y. 2018. Conceptual Approaches in Providing the Effective and Responsible Management of State Programs Management in Russia. European Research Studies Journal, 21(S1).

Romanovskiy, M.V., Vrublevskaya, O.V., Sabanti, B.M. 2000. Finance: Textbook for universities. Moscow, Publishing House Perspective, Urayt, 154.

Strelnikova, S.A. 2018. On opposite sides of the ranking. Available at: http://bujet.ru. 